\title{
Pelatihan Penyusunan Instrumen Evaluasi Aktifitas Gerak Bagi Fasilitator Kinder Movement
}

\author{
${ }^{1}$ M E Winarno, ${ }^{2}$ Dona Sandy Yudasmara, ${ }^{3}$ Taufik, ${ }^{4}$ Nurrul Riyad Fadhli \\ ${ }^{12}$ Jurusan Pendidikan Jasmani dan Kesehatan, Fakultas Ilmu Keolahragaan, Universitas \\ Negeri Malang \\ ${ }^{34}$ Jurusan Pendidikan Kepelatihan Olahraga, Fakultas Ilmu Keolahragaan, Universitas \\ Negeri Malang \\ Email: m.e.winarno.fik@um.ac.id ${ }^{1}$, dona.sandy.fik@um.ac.id ${ }^{2}$, Taufik.fik@um.ac.id ${ }^{3}$, \\ nurrul.riyad.fik@um.ac.id ${ }^{4}$
}

Diterima: 19 Desember 2019; Revisi: 20 March2020; Disetujui: 05 May 2020

\begin{abstract}
Abstrak
Kegiatan pengabdian masyarakat bertujuan untuk memberikan pengetahuan, pengalaman dan pelatihan berkaitan dengan penyusunan instrumen penilaian aktifitas fisik anak dalam bentuk kartu rapor. Metode pelatihan yang digunakan terdiri pelatihan teoritis dan praktis. Teori-teori tes, pengukuran assesmen dan evaluasi akan diberikan secara klasikal dan praktik. Respon fasilitator terhadap penyelenggaraan pengabdian pelatihan sangat baik, sehingga fasilitator sudah dapat mengimplementasikan materi yang di dapat pada pengembangan instrumen penilaian aktifitas gerak yang terdapat pada jurnal kegiatan harian
\end{abstract}

Kata kunci: Kartu Rapor, penilaian, sikap, pengetahuan, keterampilan.

\section{Abstract}

Community service activities aimed to provide knowledge, experience and training related to the preparation of physical activity assessment instruments for children in the form of report cards. The training method used consists of theoretical and practical training. Test theories, assessment measures and evaluations will be given classically and in practice. The facilitator's response to the organization of training was very good, so the facilitator was able to implement the material obtained in the development of the motion activity assessment instrument contained in the daily activity journal.

Keywords: Reports Card, Assessment, Cognitive, Affective, Psychomotor.

\section{ANALISIS SITUASI}

Keberhasilan pembelajaran aktifitas gerak ditentukan oleh beberapa aspek, seperti aspek perencanaan, pelaksanaan dan penilaian hasil kegiatan. Faktor lain yang dapat meningkatkan kualitas aktifitas fisik ditentukan oleh ketersediaan fasilitas ruang terbuka yang memadai dan peralatan penunjang. Ketersediaan SDM, sarana prasarana dapat mempengaruhi kualitas dan optimali proses pembelajaran (Turner, Johnson, Calvert, \& Chaloupka, 2017). Proses perencanaan fasilitator harus menyususun jurnal kegiatan harian, serta menyiapan media dan sumber belajar, perangkat penilaian aktifitas gerak, dan skenario alur pendampingan.

Proses pelaksanaan atau tahap tranformasi akan memberikan pengalaman belajar yang melibatkan proses mental dan fisik melalui interaksi antar siswa, siswa dengan fasilitator, lingkungan dan sumber belajar lainnya dalam rangka mencapai tujuan kompetensi dasar. 


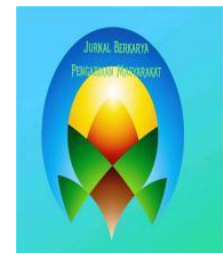

Journal Berkarya

Pengabdian kepada Masyarakat Vol. 2, No.1, Mei, 2020,

E - ISSN 2686-6218

Link: http://jba.ppj.unp.ac.id/index.php/jba Doi: https://doi.org/10.24036/ jba.v\%vi\%i.38

Penilaian hasil belajar merupakan proses kegiatan pengumpulan dan pengolahan informasi untuk mengukur capaian hasil belajar siswa.

Asesmen merupakan salah satu bagian penting yang harus dilakukan fasilitator. Penilaian yang baik memberikan dampak pada proses pembelajaran (Popham, 2009). Penilaian dilakukan agar dapat memberikan umpan balik kepada peserta didik maupun pendidik tentang efektivitas pendidikan yang telah dilakukan (Pellegrino, 2001). Proses penilaian untuk mengukur apakah pelaksanaan pembelajaran sudah mencapai tujuan atau belum merupakan bagian dari asesmen.

Pengumpulan informasi yang dilakukan dalam kegiatan fasilitasi aktifitas gerak biasa menggunakan dua pendekatan; (1) tes dan (2) non tes. Keduanya digunakan untuk mendeteksi apakah pembelajaran yang dilakukan sudah berhasil (mencapai tujuan), apakah siswa sudah mencapai kemajuan belajar yang signifikan, dan sebagainya. Mengetahui kemajuan belajar siswa merupakan bagian penting dalam pendidikan. Aspek penilaian Pelatihan penyusunan model aktifitas fisik untuk anak meliputi: (1) sikap, (2) pengetahuan, dan (3) keterampilan. Hal tersebut selaras dengan pendapat (Stolz, 2013). yang mengemukakan bahwa aspek penilaian pendidikan jasmani di sekolah meliputi: (1) aspek fisik, (2) keterampilan, (3) pengetahuan dan sikap.

Pengembangan instrumen penilaian aktifitas fisik, penerapan model asesmen dan analisis hasil belajar siswa dalam aktifitas fisik, merupakan materi penting yang harus dikuasai setiap fasilitator, sehingga fasilitator kinder movement indonesia dapat mengembangkan instrumen asesmen, menerapkan model asesmen \& melakukan analisis terhadap hasil belajar yang dimiliki siswa secara tepat. Ketepatan pemilihan dan penggunaan instrumen tes, pengukuran dan evaluasi merupakan kebutuhan yang harus dipenuhi oleh fasilitator kinder movement indonesia.

Dengan demikian pemahaman konsep pengembangan instrumen, penerapan model asesmen dan analisis hasil aktifitas peserta dalam aktifitas fisik merupakan komponen penting yang diperlukan oleh fasilitator kinder movement. Fasilitator Kinder Movement Indonesia sebagai tenaga profesional dalam melaksanakan tugasnya sehari-hari harus menyiapkan tiga hal: (1) menyusun jurnal kegiatan, (2) melaksanaakan kegiatan pembelajaran, dan (3) melakukan evaluasi pelaksanaan kegiatan. Ketiga kegiatan tersebut harus dilakukan fasilitator Kinder Movement Indonesia.

Setiap kegiatan pembelajaran harus diikuti dengan penilaian, apakah pembelajaran yang dilakukan, memiliki dampak terhadap perolehan hasil belajar berupa: perbaikan sikap, peningkatan pengetahuan, dan keterampilan. Keberhasilan tiga aspek tujuan pembelajaran tersebut akan dinilai, karena ketiganya merupakan tagihan keberhasilan tujuan dan sasaran kegiatan tersebut dilakukan. Sebuah instrumen penilaian yang baik harus memiliki validitas yang tinggi, reliabel dan objektif. Penilaian Pelatihan penyusunan model aktifitas fisik untuk anak yang baik, didasarkan pada sajian materi fasilitasi aktifitas gerak setiap pertemuan maupun dalam satu batch. Materi yang diujikan dan dinilai oleh fasilitator adalah materi yang telah dilaksanakan sesuai dengan jurnal kegiatan dalam aktifitas pada setiap batch tertentu.

Dalam kegiatan fasilitasi aktifitas fisik atau keterampilan terdapat dua jenis evaluasi, yaitu jenis evaluasi tes dan pengukuran. Istilah tes berasal dari bahasa prancis, yaitu testum berarti piring yang digunakan untuk memilih logam mulia dari benda-benda lain. Tes adalah sebuah instrument yang dipakai untuk memperoleh informasi tentang seseorang atau obyek.

Sedangkan pengertian pengukuran adalah penentuan besaran, dimensi, atau kapasitas, biasanya terhadap suatu standar atau satuan pengukuran. Pengukuran tidak hanya terbatas pada kuantitas fisik, tetapi juga dapat diperluas untuk mengukur hampir semua benda yang bisa dibayangkan, seperti tingkat ketidakpastian, atau kepercayaan konsumen. Pengukuran ialah proses pengumpulan informasi. adalah sebagai pemberian angka-angka pada obyek atau kejadian-kejadian menurut suatu aturan tertentu (Winarno, 2006). 


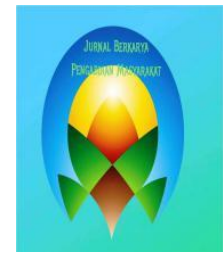

Journal Berkarya

Pengabdian kepada Masyarakat Vol. 2, No.1, Mei, 2020, E - ISSN 2686-6218

Link: http://jba.ppj.unp.ac.id/index.php/jba Doi: https://doi.org/10.24036/ jba.v\%vi\%i.38

Pemberian fasilitasi aktifitas fisik yang dilakukan dalam satu periode tertentu harus memenuhi tujuan sesuai dengan kompentensi yang ditetapkan. Tujuan dapat dikatakan tercapai apabila indikator dari tujuan tersebut dapat terselesaikan. Indikator merupakan penanda atau acuan penguasaan materi yang diberikan dan sebagai dasar untuk memutuskan apakah subjek mampu menerima materi ajar yang diberikan oleh fasilitator. Untuk mengetahui hal tersebut dibutuhkan alat untuk mengetahui pencapaian hasil pembelajaran yang dilaksanakan. Proses mengetahui hasil pembelajaran adalah dengan menggunakan evaluasi hasil belajar.

Evaluasi pembelajaran merupakan salah satu tahap dari pelaksanaan pembelajaran untuk menafsirkan hasil yang diraih peserta didik. Dengan kemampuan yang dimiliki oleh fasilitator dalam menyusun instrumen penilaian aktifitas fisik anak maka diharapkan komptensi anak didik akan dapat diketahui dengan baik serta fasilitator dapat menyusun instrumen tes yang terstandar dan memiliki kriteria yang baik sehingga dapat digunakan pada khalayak luas.

\section{SOLUSI DAN TARGET}

Kegiatan Pelatihan penyusunan instrument penilaian model aktifitas fisik untuk anak harus juga menyesuaikan dengan jurnal kegiatan yang disusun oleh fasilitator. Pelaksanaan pembelajaran yang baik adalah pembelajaranan yang dilakukan sesuai dengan perencanaan yang dilakukan. Jika pelaksanaan Pelatihan penyusunan model aktifitas fisik untuk anak tidak sesuai dengan jurnal kegiatan, maka keduanya harus dievaluasi (cek ulang).

Berdasarkan pendahuluan di depan, maka penyamaan persepsi terhadap proses penyusunan instrumen evaluasi akktifitas fisik dan penilaian aktifitas fisik anak secara terstandar memiliki peran penting untuk dilakukan oleh fasilitator Kinder Movement Indonesia. Kegiatan pelatihan penyusunan instrumen evaluasi aktifitas fisik ini memiliki tujuan untuk menyamakan persepsi meningkatkan keahlian fasilitator tentang penyusunan instrumen sikap, pengetahuan dan keterampilan dalam kegiatan fasilitasi aktifitas fisik untuk anak usia dini.

\section{METODE PELAKSANAAN}

Berisi deskripsi tentang proses perencanaan aksi bersama komunitas (pengorganisasian komunitas). Dalam hal ini dijelaskan siapa subyek pengabdian, tempat dan lokasi pengabdian, keterlibatan subyek dampingan dalam proses perencanaan dan pengorganisasian komunitas, metode atau strategi riset yang digunakan dalam mencapai tujuan yang diharapan dan tahapantahapan kegiatan pengabdian masyarakat. Proses perencanaan dan strategi/metode digunakan gambar flowcart atau diagram.

\section{PELAKSANAAN KEGIATAN}

\section{Tempat dan Waktu.}

Pelaksanaan pelatihan dilakukan selama 2 hari mulai dari Rabu-Kamis, 5-6 Juni 2019 bertempat di Fakultas Ilmu Keolahragaan Universitas Negeri Malang.

\section{Metode Evaluasi.}

Evaluasi untuk pelaksanaan Pelatihan Penyusunan Aktivitas Jasmani bagi fasilitator Kinder Movement sebagai upaya peningkatan branding usaha jasa mahasiswa sebagai berikut:

1. Penugasan untuk menyusun konten utama materi

2. Portofolio

\section{HASIL DAN PEMBAHASAN}

\section{a) Hasil Kegiatan}

Kegiatan pengabdian pelatihan dilaksanakan pada hari Rabu-Kamis, 5-6 Juni 2019 di Fakultas Ilmu Keolahragaan Universitas Negeri Malang. Topiknya adalah penyusunan instrumen penilaian aktifitas fisik untuk anak usia dini. Peserta pelatihan yaitu seluruh 


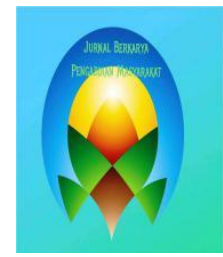

Journal Berkarya

Pengabdian kepada Masyarakat Vol. 2, No.1, Mei, 2020,

E - ISSN 2686-6218

Link: http://jba.ppj.unp.ac.id/index.php/jba Doi: https://doi.org/10.24036/ jba.v\%vi\%i.38

Fasilitator Kinder Movement Indonesia di Kota Malang. Kegiatan pelatihan penyusunan instrumen penilaian aktifitas fisik anak usia dini terdiri atas beberapa kegiatan. Adapun rincian kegiatan pelatihan dapat dilihat tabel berikut ini.

Tabel 2. Rincian Kegiatan Pelatihan

\begin{tabular}{cl}
\hline Tahap & \multicolumn{1}{c}{ Pelaksanaan Kegiatan } \\
\hline Kegiatan Awal & Penyampaian Materi Tentang Terminologi Evaluasi Penilaian Aktifitas Fisik Dan \\
& Konsep Penyusunan Instrumen Sikap, Pengetahuan Oleh Ketua Kegiatan Pelatihan \\
& Prof. Dr. M.E. Winarno. M.Pd. \\
Kegiatan Inti & Praktik Penyusunan Instrumen Penilaian dan Analisis hasil Penyusunan Instrumen \\
& Penilaian Sikap, Pengetahuan, dan Keterampilan aktifitas fisik untuk anak usia dini \\
& oleh Dona Sandy Yudasmara, S.Pd,M.Pd, Nurrul Riyad Fadhli, S.Pd., M.Or.dan \\
& Taufik, S.Pd., M.Or \\
Kegiatan Akhir & $\begin{array}{l}\text { Penetapan bentuk Rapor (Report Card) untuk Kegiatan Aktifitas Fisik yang } \\
\text { dilakukan oleh anak usia Dini sebagai acuan untuk penyusunan rapor per kegiatan } \\
\end{array}$ \\
& maupun rapor akhir keseluruhan. \\
\hline
\end{tabular}

Kegiatan awal dilakukan pada hari Rabu, 5 Juni 2019 tentang terminologi evaluasi pembelajaran dan konsep penyusunan instrumen sikap, pengetahuan dan keterampilan oleh ketua kegiatan pelatihan Prof. Dr. M.E. Winarno. M.Pd. Tujuan kegiatan awal ini adalah membekali pengetahuan Fasilitator Kinder Movement Indonesia dan menyamakan persepsi tentang konsep penilaian dan langkah-langkah penyusunan instrumen penilaian pelajaran aktifitas fisik untuk anak usia dini.Secara keseluruhan materi yang disampaikan dalam kegiatan awal ini yaitu konsep assessment dan evaluasi, konsep tes dan pengukuran, identifikasi tes dan pengukuran, dan proses langkah penyusunan instrumen penilaian.

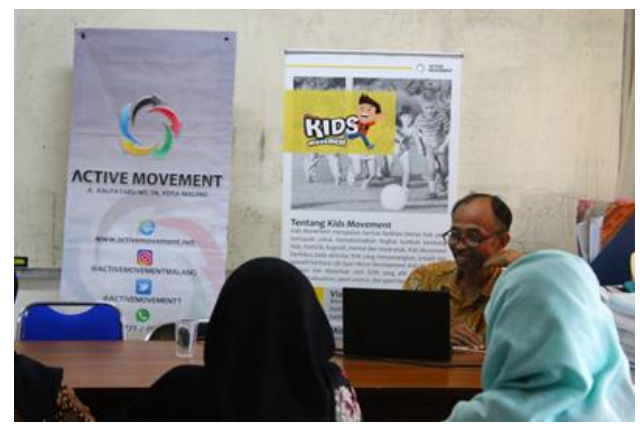

\section{Gambar 1. Tim Memberikan Materi Konsep Penilaian}

Kegiatan inti yang berikutnya dilaksanakan pada hari Kamis 6 Juni 2019 dengan kegiatan praktik dan pendampingan penyusunan instrumen penilaian dan analisis hasil penyusunan instrumen penilaian sikap, pengetahuan, dan keterampilan Pelatihan penyusunan model aktifitas fisik untuk anak oleh Dona Sandy Yudasmara, S.Pd, M.Pd Nurrul Riyad Fadhli, S.Pd., M.Or dan Taufik, S.Pd., M.Or Tujuannya untuk meningkatkan kemampuan fasilitator dalam menyusun assesmen penilaian sikap, pengetahuan dan keterampilan. 


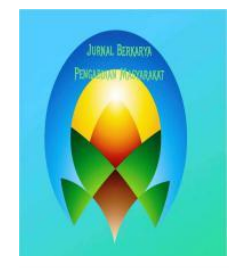

Journal Berkarya

Pengabdian kepada Masyarakat Vol. 2, No.1, Mei, 2020,

E - ISSN 2686-6218

Link: http://jba.ppj.unp.ac.id/index.php/jba Doi: https://doi.org/10.24036/ jba.v\%vi\%i.38

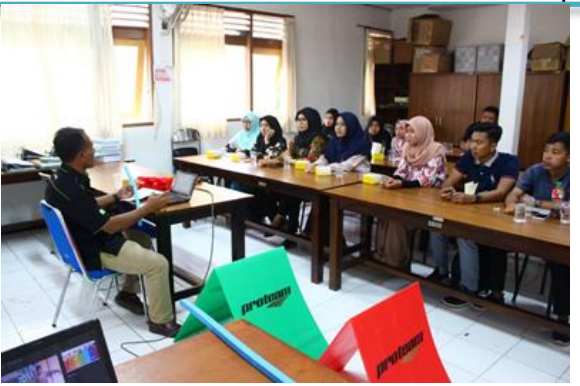

\section{Gambar 2. Tim Memberikan Materi dan Pendampingan Penyusunan Instrumen Penilaian}

Pada kegiatan ini fasilitator diwajibkan membawa contoh Jurnal Kegiatan Harian yang telah disusun sebelumnya. Kemudian bersama-sama mengidentifikasi dari mulai tujuan pelaksanaan kegiatan, sasaran kegiatan, point atau aspek yang ditingkatkan, rencana kegiatan dan tahap penilaian yang tertulis di Jurnal Kegiatan. Dari identifikasi ini diharapkan para fasilitator menemukan atau mengetahui tata cara penulisan maupun kesalahan-kesalahan dalam perumusan instrumen penilaian yang sudah disusun. Selanjutnya para fasilitator Kinder Movement melakukan praktik membuat instrumen penilaian dengan didampingi oleh tim pelatihan.

Kegiatan akhir dari pelatihan ini adalah diskusi dan penetepan format baku kartu rapor (Report Card) untuk aktiftas fisik anak usia dini yang nantinya akan digunakan sebagai panduan dalam kegiatan yang dilakukan selanjutnya. Kartu rapor ini terdiri atas kartu rapor harian dan kartu rapor akhir keseluruhan rangkaian kegiatan

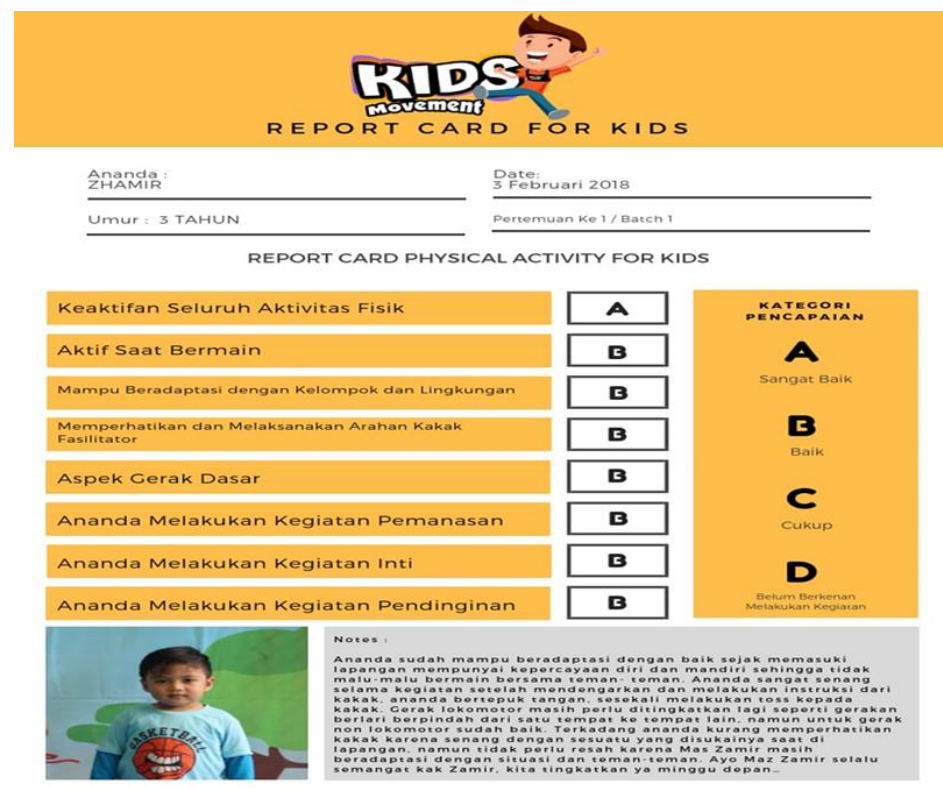

Gambar 3. Report Card untuk aktifitas Fisik Anak

\section{b) Pembahasan}

Kebugaran jasmani sangat penting untuk dimiliki oleh setiap anak, semakin tinggi tingkat kesegaran jasmani seorang anak, maka akan semakin tinggi pula motivasi atau semangat anak untuk melakukan kegiatan-kegiatan kesehariannya seperti menjalankan tugasnya sebagai seorang pelajar yaitu belajar. Pendidikan Jasmani dapat meningkatkan 


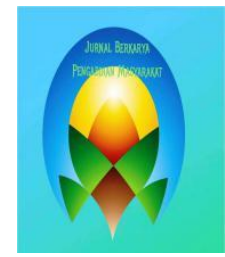

Journal Berkarya

Pengabdian kepada Masyarakat Vol. 2, No.1, Mei, 2020,

E - ISSN 2686-6218

Link: http://jba.ppj.unp.ac.id/index.php/jba Doi: https://doi.org/10.24036/ jba.v\%vi\%i.38

perilaku dalam kegiatan belajar terutama keterampilan-keterampilan yang terkait dengan saintifik (Álvarez-Bueno et al., 2017). Pendidikan jasmani atau berolahraga pada siswa sekolah dasar dilakukan dengan cara mengembangkan kemampuan fisik motoriknya melalui olahraga. Ketika berolahraga, anak menggerakan otot-otot tubuhnya yang merupakan stimulasi bagi perkembangan motorik terutama motorik kasar.

Olahraga yang tepat sebagai stimulasi perkembangan motorik tersebut adalah yang sesuai dengan usia dan perkembangan anak. Ketika Pendidikan Jasmani disajikan secara tepat, diprogramkan sedemikian rupa dengan baik maka akan dapat membina domain fisik, gaya hidup, afektif, sosial, dan kognitif serta memungkinkan terjadinya interaksi antara anak, guru dan orang tua secara baik dan kepuasan kerja dari guru maupun siswa dapat meningkat (Bailey et al., 2009; Wang, Shen, Luo, Hu, \& Garn, 2018).

Hasil penelitian terbaru mencatat pengguna internet di Indonesia yang berasal dari kalangan anak-anak dan remaja diprediksi mencapai 30 juta. Penelitian juga mencatat ada kesenjangan digital yang kuat antara anak dan remaja yang tinggal di perkotaan dengan yang tinggal di pedesaan. Data tersebut merupakan hasil penelitian yang dilakukan lembaga PBB untuk anak-anak, UNICEF, bersama para mitra, termasuk Kementerian Komunikasi dan Informatika dan Universitas Harvard, AS.

Studi ini menelusuri aktivitas online dari sampel anak dan remaja yang melibatkan 400 responden berusia 10 sampai 19 tahun di seluruh Indonesia dan mewakili wilayah perkotaan dan pedesaan. Sebanyak 98 persen dari anak dan remaja mengaku tahu tentang internet dan 79,5 persen di antaranya adalah pengguna internet. Dalam penelitian ini terdapat sekitar 20 persen responden yang tidak menggunakan internet.

Alasan utamanya adalah tidak memiliki perangkat atau infrastruktur untuk mengakses internet atau mereka dilarang oleh orang tua untuk mengakses internet. Anak-anak yang menggunakan gawai secara tidak langsung mendapat kemudahan terhadap akses informasi, tetapi cenderung membatasi aktifitas bermain dengan teman sebaya. Pada penelitian lain menyebutkan bahwa pengaruh permainan daring memberikan dampak ketergantungan anak terhadap hal tersebut (Broto, 2014; Istiyanto, 2016; Pradekso Turnomo; Indriani, Devi Pranasningtias, 2013).

Terkait data tersebut di atas, aktifitas gerak anak di Indonesia berkurang dikarenakan adanya internet yang berada di genggaman tangan melalui smartphone mereka. Berkurangnya aktifitas gerak akan mempengaruhi tingkat kebugaran fisik seseorang. Kualitas belajar siswa salah satunya dipengaruhi oleh tingkat kebugaran fisiknya. Gaya hidup yang lebih aktif secara fisik dapat memberikan manfaat bagi pengembangan keterampilan membaca pada anak lakilaki pada tahun pertama sekolah (Haapala et al., 2017).

Faktor yang mempengaruhi tingkat kebugaran jasmani siswa menurut adalah umur, jenis kelamin, somatotipe, kondisi kesehatan, status gizi, berat badan, waktu istirahat serta aktifitas jasmaniah. Dari pendapat tersebut dapat ditelaah aktifitas jasmaniah memegang peranan yang cukup penting terhadap status kebugaran jasmani seseorang. Kasus obesitas terhadap anak seringkali terjadi dikarenakan rendahnya aktifitas fisik anak. Anak yang aktif bergerak dengan berbagai macam variasi aktifitas fisik cenderung terhindar dari masalah obesitas (Collings et al., 2013).

Secara pasti tingkat kesegaran jasmani hanya dapat diketahui melalui tes dan pengukuran yang dilakukan oleh setiap orang. Aktifitas jasmani merupakan aktifitas yang melibatkan keseluruhan bagian tubuh dan pengeluaran energi. pengukuran aktifitas tersebut berhubungan dengan frekuensi, durasi, intensitas dan jenis perilaku pada waktu tertentu, dilakukan dengan pengadministrasian data maupun dengan sensor gerak secara langsung, berlangsung dalam waktu tertentu maupun selamanya (Ainsworth, Cahalin, Buman, \& Ross, 2015). Untuk mengetahui dan menilai tingkat kesegaran jasmani seseorang dapat dilakukan dengan pengukuran performa gerak maupun kapasitas fisik. Pengukuran kesegaran jasmani 


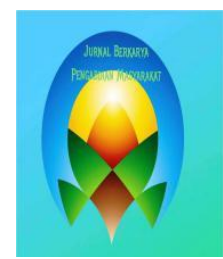

Journal Berkarya

Pengabdian kepada Masyarakat Vol. 2, No.1, Mei, 2020,

E - ISSN 2686-6218

Link: http://jba.ppj.unp.ac.id/index.php/jba Doi: https://doi.org/10.24036/ jba.v\%vi\%i.38

dilakukan dengan tes kesegaran jasmani. Untuk melakukan tes diperlukan adanya alat/instrumen.

\section{Diskusi}

Target luarannya terhadap mitra adalah meningkatnya keahlian fasilitator dalam menyusun instrumen evaluasi aktifitas fisik anak usia dini.

Memperhatikan permasalahan yang ada kegiatan pengabdian kepada masyarakat ini dilaksanakan dalam bentuk pelatihan yang digunakan terdiri pelatihan teoritis dan praktis.

Tabel 1. Metode Pelaksanaan Kegiatan

\begin{tabular}{|c|c|c|c|}
\hline Tahap & Rencana Kegiatan & Metode/Pendekatan & Tujuan/Luaran \\
\hline 1 & $\begin{array}{l}\text { Terminologi Evaluasi Pembelajaran } \\
\text { dan Penyusunan Instrumen Sikap, } \\
\text { Pengetahuan }\end{array}$ & Ceramah & $\begin{array}{l}\text { Fasilitator Kinder } \\
\text { Movement mampu } \\
\text { menguasai konsep } \\
\text { penilaian Aktifitas Fisik } \\
\text { Anak }\end{array}$ \\
\hline 2 & $\begin{array}{l}\text { Penyusunan Instrumen } \\
\text { Keterampilan }\end{array}$ & Ceramah & $\begin{array}{l}\text { Fasilitator Kinder } \\
\text { Movement Indonesia } \\
\text { mampu menguasai } \\
\text { langkah-langkah } \\
\text { penyusunan instrumen } \\
\text { penilaian Aktifitas Fisik } \\
\text { Anak }\end{array}$ \\
\hline 3 & $\begin{array}{l}\text { Praktik Penyusunan Instrumen } \\
\text { Penilaian Aktifitas Fisik Anak }\end{array}$ & Ceramah dan Praktikum & $\begin{array}{l}\text { Instrumen Penilaian sikap, } \\
\text { pengetahuan dan } \\
\text { keterampilan }\end{array}$ \\
\hline 4 & $\begin{array}{l}\text { Analisis hasil Penyusunan } \\
\text { Instrumen Penilaian Sikap, } \\
\text { Pengetahuan, dan Keterampilan } \\
\text { Aktifitas Fisik Anak }\end{array}$ & Ceramah dan Praktikum & $\begin{array}{l}\text { Instrumen Penilaian sikap, } \\
\text { pengetahuan dan } \\
\text { keterampilan Aktifitas } \\
\text { Fisik Anak }\end{array}$ \\
\hline
\end{tabular}

\section{KESIMPULAN}

Peningkatan kompetensi fasilitator dalam pengajaran sangat penting, karena keberhasilan proses pembelajaran tergantung pada fasilitator. Dalam kegiatan pengabdian Fasilitator Kinder Movement dapat menguasai konsep dan langkah-langkah serta penyusunan instrumen serta mampu menyusun instrumen penilaian aktifitas fisik untuk anak usia dini.

\section{PENGAKUAN}

Sasaran dari program pengabdian kepada masyarakat ini adalah seluruh Fasilitator Kinder Movement Indonesia di Kota Malang yang berjumlah 15 orang. Kinder Movement merupakan wadah literasi gerak anak yang didirikan dibawah naungan lembaga Active movement Indonesia. Lembaga Active Movement Indonesia ini yang membawahi kegiatan Kinder movement sebagai mitra berperan sebagai wadah mahasiswa dan alumni untuk membuat peluang kerja yang baru di era revolusi 4.0.

\section{DAFTAR PUSTAKA}

Ainsworth, B., Cahalin, L., Buman, M., \& Ross, R. (2015). The Current State of Physical Activity Assessment Tools. Progress in Cardiovascular Diseases. https://doi.org/10.1016/j.pcad.2014.10.005.

Álvarez-Bueno, C., Pesce, C., Cavero-Redondo, I., Sánchez-López, M., Garrido-Miguel, M., \& Martínez-Vizcaíno, V. (2017). Academic Achievement and Physical Activity: A Metaanalysis. Pediatrics. https://doi.org/10.1542/peds.2017-1498. 
Bailey, R., Armour, K., Kirk, D., Jess, M., Pickup, I., \& Sandford, R. (2009). The educational benefits claimed for physical education and school sport: An academic review. Research Papers in Education. https://doi.org/10.1080/02671520701809817

Broto, G. S. D. (2014). Riset Kominfo dan UNICEF Mengenai Perilaku Anak dan Remaja Dalam Menggunakan Internet.

Collings, P. J., Brage, S., Ridgway, C. L., Harvey, N. C., Godfrey, K. M., Inskip, H. M., ... Ekelund, U. (2013). Physical activity intensity, sedentary time, and body composition in preschoolers. American Journal of Clinical Nutrition. https://doi.org/10.3945/ajcn.112.045088.

Haapala, E. A., Väistö, J., Lintu, N., Westgate, K., Ekelund, U., Poikkeus, A. M., ... Lakka, T. A. (2017). Physical activity and sedentary time in relation to academic achievement in children. Journal of Science and Medicine in Sport. https://doi.org/10.1016/j.jsams.2016.11.003.

Istiyanto, S. B. (2016). TELEPON GENGGAM DAN PERUBAHAN SOSIAL Studi Kasus Dampak Negatif Media Komunikasi dan Informasi Bagi Anak-Anak di Kelurahan Bobosan Purwokerto Kabupaten Banyumas. Jurnal Komunikasi Ikatan Sarjana Komunikasi Indonesia. https://doi.org/10.25008/jkiski.v1i1.36.

Pellegrino, E. D. (2001). The Internal Morality of Clinical Medicine: A Paradigm for the Ethics of the Helping and Healing Professions. The Journal of Medicine and Philosophy, 26(6), 559-579. https://doi.org/10.1076/jmep.26.6.559.2998.

Popham, W. J. (2009). Assessment literacy for teachers: Faddish or fundamental? Theory into Practice, 48(1), 4-11. https://doi.org/10.1080/00405840802577536.

Pradekso Turnomo; Indriani, Devi Pranasningtias, T. R. (2013). Hubungan Intensitas Penggunaan Game Online, Pengawasan Orang Tua terhadap Anak, dengan Prestasi Belajar Anak. Interaksi Online.

Stolz, S. A. (2013). Phenomenology and Physical Education. Educational Philosophy and Theory. https://doi.org/10.1080/00131857.2013.785355.

Turner, L., Johnson, T. G., Calvert, H. G., \& Chaloupka, F. J. (2017). Stretched too thin? The relationship between insufficient resource allocation and physical education instructional time and assessment practices. Teaching and Teacher Education, 68, 210-219. https://doi.org/10.1016/j.tate.2017.09.007.

Wang, J., Shen, B., Luo, X., Hu, Q., \& Garn, A. C. (2018). Validation of a teachers' achievement goal instrument for teaching physical education. Journal of Teaching in Physical Education. https://doi.org/10.1123/jtpe.2016-0210.

Winarno, M. E. (2006). Dimensi Pembelajaran Pendidikan Jasmani Dan Olahraga. In Laboratorium Jurusan Ilmu Keolahragaan Fakultas Ilmu Pendidikan Universitas Negeri Malang. 